\title{
RESORPTION OF INTRACUTANEOUSLY INJECTED CONGO RED*
}

\author{
BY \\ R. A. PARKINS AND E. G. L. BYWATERS \\ From the Department of Medicine Post-Graduate Medical School of London, \\ and the Rheumatism Research Unit (M.R.C.), Canadian Red Cross Memorial Hospital, Taplow
}

Since the introduction of the intravenous Congo red test by Bennhold (1923), a number of writers have recorded observations on the intracutaneous injection of Congo red dye.

Philpott and Freshman (1936) and Nomland (1936) observed intense and prolonged staining of cutaneous amyloid deposits in patients following the local injection of Congo red solution.

Laine, Holopainen, and Mäkinen (1956) noted that Congo red solution injected into the apparently healthy skin of a group of rheumatoid arthritics disappeared more slowly than in control subjects. Shannon, Fessel, and Bywaters (1957) confirmed Laine's findings in a group of juvenile arthritics and observed that the delay in fading was most marked in the younger age groups. They noted that another dye, Evans' blue, failed to show this difference in fading.

No cause is known for this apparent dermal avidity for Congo red in patients with rheumatoid arthritis, but Shannon and others suggest a relationship to the increased tissue retention of intravenously injected Congo red demonstrated in these subjects by Dixon, Ramcharan, and Ropes (1955). If this were so, then the skin of rheumatoid patients with secondary amyloidosis might be expected to show this delay in fading rate, perhaps to a more marked degree.

The purpose of this paper is to report a study of the fading rate of intracutaneously injected Congo red in a group of mainly adult patients with rheumatoid arthritis and to compare these with a small group of patients with amyloidosis. The results are compared with those in a control group.

\section{Methods}

The method was similar to that used by Laine and others (1956) and modified by Shannon and others

\footnotetext{
* Paper read at a clinical meeting of the Heberden Society on December 5, 1958 .
}

(1957), with the exception that aqueous 1 per cent. Congo red was used instead of a saline solution, as it was found. that a deposit occurred if the saline solution was allowed $\overrightarrow{0}$ to stand for 24 to 48 hours.

$0.1 \mathrm{ml}$. aqueous 1 per cent. Congo red solution? (Savory and Moore) was injected into the medial aspect of the forearm or upper arm. A red area 1 to $3 \mathrm{~cm}$ o in diameter was formed, which at 24 hours was compared⿳亠丷厂 with a series of standards labelled 1 to 8 , produced by dyeing Whatman No. 1 filter paper in serial dilutions of Congo red solution 0.25 to 0.00195 per cent. AC reading was then taken, and after an interval of 7 days a second reading was made. An arbitrary index indicat-o ing "Fading Rate", hereafter designated F.R., wascalculated by dividing the number of degrees of fading by the interval in days. The higher the F.R. the greatero the rate of fading of the Congo red.

In the presence of jaundice or other skin pigmentation, $\overrightarrow{\vec{\nexists}}$ the red tint of the Congo red was altered, but the intensity of the skin coloration could usually be matched without difficulty.

During the course of the investigation a number of factors thought possibly to influence the F.R. were investigated.

Site of Injection.-The fading rates in the upper arm and forearm were compared by simultaneous injections of the solution. The mean of tests performed in ten patients showed an F.R. of 0.6 for the upper arm and 0.56 for the forearm. These figures do not differ? significantly.

In a few patients the effect of altering the volume of dye injected was observed by comparing the F.R. of N $0.1 \mathrm{ml}$. and $0.2 \mathrm{ml}$. injected into opposite arms. This did not seem to influence the results.

Repeatability.-Serial tests were performed on ${ }^{\mathrm{\omega}}$ number of patients and controls and close agreement was? found in subjects with normal and abnormal F.Rs.

Comparison of Aqueous and Saline Solutions of Congow Red.-To determine if the solvent for the Congo red influenced the F.R., the aqueous solution was comparedwith a saline preparation. One per cent. aqueous Congo red was mixed with an appropriate volume of 20 per? cent. sodium chloride solution to give a final concen- $\mathbb{Q}$ tration of 0.9 per cent. This was allowed to stand foro 
48 hours and centrifuged to remove any deposit. The resulting solution was compared colorimetrically with the 1 per cent. aqueous solution and the latter diluted with pyrogen-free distilled water to render the concentration equal. The solution was then autoclaved.

Thirteen patients were tested by observing the F.R. of the aqueous and saline solutions in opposite arms. The mean fading rate for the aqueous solution was 0.68 and for the saline solution of Congo red $0 \cdot 65$. Similar results were obtained when the saline solution was injected immediately after preparation. Clearly then the use of a saline solution does not influence the results significantly.

\section{Subjects}

The rheumatoid arthritis subjects were mainly inpatients in the Hammersmith Hospital; a small number of the younger patients were seen at the Rheumatism Research Unit of the Canadian Red Cross Memorial Hospital, Taplow.

The control group of subjects included healthy members of the staff, and other in-patients with diseases other than rheumatoid arthritis (e.g. hypertensive and ischaemic heart disease, and gastro-intestinal and respiratory diseases) of all age groups.

\section{Results}

The F.Rs. in both rheumatoid and non-rheumatoid subjects are shown in Table I with subdivision into sex and age groups, together with the standard deviations for each group.

Rheumatoid Group.- The group of 66 rheumatoid arthritics included 45 females and 21 males. Their ages varied between $6 \frac{1}{2}$ and 85 years (mean 46 yrs in males; 47 yrs in females). The mean F.R. for the females was 0.61 and for the males $0.62(-$ S.E. 0.04
(S.D. 0.21)). Although the numbers in the subgroups are small, there does not seem to be a significant variation with age; however, two of thirteen subjects below the age of 20 years had F.Rs. of less than $0 \cdot 3$, while only two of 53 subjects above the age of 20 years had abnormal F.Rs.

If only patients with a positive Rose-Waaler (D.A.T.) test are considered, the mean F.R. was 0.63 ( \pm S.E. 0.04 (S.D. 0.16)). Similarly, in a group of patients described as having active disease with erythrocyte sedimentation rates above $20 \mathrm{~mm}$./ $\mathrm{hr}$, the F.R. was $0 \cdot 61$.

Effects of Steroid Hormones.-As a number of these rheumatoid patients were receiving steroid hormones, the influence of these steroids was observed in a group of nine patients with rheumatoid arthritis and two with other diseases; the F.R. was determined both before and during the course of treatment with steroid hormones.

The group included subjects with both normal and abnormal F.Rs. and the dose of hormone used varied between 50 and $150 \mathrm{mg}$. cortisone and 10 and $30 \mathrm{mg}$. prednisolone daily. The mean F.R. without steroid treatment was 0.60 and with the hormone $0 \cdot 55$. This difference was not significant.

In another group of five patients, hydrocortisone acetate was added to the Congo red solution before injection, in a dose of approximately $10 \mathrm{mg} . / \mathrm{ml}$, i.e. $1 \mathrm{mg}$. in each injected dose. Once again no significant difference in F.R. was observed from that of the aqueous solution in the opposite arm.

Control Group.-The non-rheumatoid control group was composed of 96 subjects, 51 female and

TABLE I

FADING RATES IN RHEUMATOID AND NON-RHEUMATOID SUBJECTS, BY AGE AND SEX

\begin{tabular}{|c|c|c|c|c|c|c|c|c|c|c|c|c|c|c|c|}
\hline \multirow{2}{*}{$\begin{array}{l}\text { Series } \\
\text { Sex }\end{array}$} & \multirow{2}{*}{$\frac{\cdots}{\cdots}$} & \multirow{2}{*}{$\frac{\cdots}{\cdots}$} & \multirow{2}{*}{$\frac{\cdots}{\cdots}$} & \multicolumn{6}{|c|}{ Non-Rheumatoid } & \multicolumn{6}{|c|}{ Rheumatoid } \\
\hline & & & & \multicolumn{3}{|c|}{ Males } & \multicolumn{3}{|c|}{ Females } & \multicolumn{3}{|c|}{ Males } & \multicolumn{3}{|c|}{ Females } \\
\hline \multicolumn{4}{|c|}{$\begin{array}{c}\text { Age Group } \\
(y \mathrm{rs})\end{array}$} & No. & $\begin{array}{c}\text { Mean } \\
\text { Age } \\
(\mathrm{yrs})\end{array}$ & $\begin{array}{l}\text { Mean } \\
\text { F.R. }\end{array}$ & No. & $\begin{array}{c}\text { Mean } \\
\text { Age } \\
\text { (yrs) }\end{array}$ & $\begin{array}{c}\text { Mean } \\
\text { F.R. }\end{array}$ & No. & $\begin{array}{c}\text { Mean } \\
\text { Age } \\
\text { (yrs) }\end{array}$ & $\begin{array}{l}\text { Mean } \\
\text { F.R. }\end{array}$ & No. & $\begin{array}{c}\text { Mean } \\
\text { Age } \\
\text { (yrs) }\end{array}$ & $\begin{array}{c}\text { Mean } \\
\text { F.R. }\end{array}$ \\
\hline $0-20$ & . & . & $\cdots$ & 0 & & & 2 & $17 \cdot 5$ & $0 \cdot 30$ & 3 & 11 & $0 \cdot 80$ & 10 & 13 & $0 \cdot 54$ \\
\hline $21-40$ & $\cdots$ & . & $\ldots$ & 12 & 34 & 0.64 & 10 & 31 & $0 \cdot 42$ & 5 & 36 & $0 \cdot 60$ & 3 & 28 & $0 \cdot 62$ \\
\hline $41-60$ & $\cdots$ & $\cdots$ & . & 20 & 54 & 0.63 & 26 & 51 & $0 \cdot 57$ & 10 & 47 & $0 \cdot 60$ & 17 & 49 & $0 \cdot 67$ \\
\hline \multicolumn{2}{|c|}{ Over 60} & . & $\cdots$ & 13 & 65 & $0 \cdot 57$ & 13 & 68 & 0.62 & 3 & 67 & $0 \cdot 54$ & 15 & 68 & $0 \cdot 59$ \\
\hline \multicolumn{3}{|c|}{ Total } & $\cdots$ & 45 & 51 & $0 \cdot 59$ & 51 & 50 & $0 \cdot 54$ & 21 & 46 & $0 \cdot 62$ & 45 & $47 \cdot 5$ & 0.61 \\
\hline & & & \multicolumn{7}{|c|}{ Total Non-Rheumatoid } & \multicolumn{6}{|c|}{ Total Rheumatoid } \\
\hline \multirow{2}{*}{\multicolumn{3}{|c|}{ Fading Rate }} & & $\begin{array}{l}\text { Mean } \\
\text { F.R. }\end{array}$ & \multicolumn{3}{|c|}{ S.E. of Mean } & \multicolumn{2}{|c|}{$\begin{array}{l}\text { Standard } \\
\text { Deviation }\end{array}$} & $\begin{array}{l}\text { Mean } \\
\text { F.R. }\end{array}$ & \multicolumn{3}{|c|}{ S.E. of Mean } & \multicolumn{2}{|c|}{$\begin{array}{l}\text { Standard } \\
\text { Deviation }\end{array}$} \\
\hline & & & & 0.56 & \multicolumn{3}{|c|}{ \pm 0.026} & \multicolumn{2}{|c|}{$0 \cdot 25$} & $0 \cdot 61$ & \multicolumn{3}{|c|}{$\therefore 0.026$} & \multicolumn{2}{|c|}{$0 \cdot 21$} \\
\hline
\end{tabular}


45 male, with ages varying from 17 to 72 years. The fading index in the female group was 0.54 and that in the male group $0.59( \pm$ S.E. 0.04 (S.D. $0 \cdot 25)$ ). The differences between these means and those of the rheumatoid group were not significant ( $p=0.6$ for males and $p=0.2$ for females).

When all the results are plotted as a scatter diagram (Fig. 1, opposite) of F.R. against age, the lack of correlation with age is clearly illustrated, and it is apparent that most results lie above the 0.3 level of F.R. This level was found to be two standard deviations below the total mean F.R. of the whole group, and levels at or below 0.3 are therefore considered abnormal. If the 28 patients with an F.R. of 0.3 or less are considered, a certain grouping of diagnoses is observed (Table II).

This Table shows that the rheumatoid patients did not contribute materially to the abnormal group, except in those cases complicated by amyloidosis. In fact, only two uncomplicated adult rheumatoid arthritis patients had an F.R. of 0.3 or less. These groups will therefore be considered separately (Table III).

Lupus Erythematosus.-The group included eight 흔 patients with systemic disease and one with chronic $\frac{\bar{m}}{\partial}$ discoid disease of long duration. All showed a $\stackrel{\oplus}{\propto}$ F.R. of 0.3 or less, and in two intense staining persisted for 9 and 7 months respectively until death. The mean F.R. in this group was $0 \cdot 13( \pm$ S.E. 0.04 (S.D. $0 \cdot 10)$ ), a highly significant difference from the rheumatoid group and the control group as a whole $(p=<0.001)$.

All the patients with systemic disease were receiving steroid hormones at the time of the test. At autopsy two patients had dye persisting at the $\vec{\infty}$ injection site and frozen sections of this area showed

TABLE II

DIAGNOSIS IN 28 PATIENTS WITH FADING RATES OF $0 \cdot 3$ OR LESS

\begin{tabular}{|c|c|c|c|c|c|c|c|c|c|c|c|}
\hline \multicolumn{10}{|c|}{ Diagnosis } & \multirow{2}{*}{$\begin{array}{c}\begin{array}{c}\text { No. of Patients } \\
\text { Tested }\end{array} \\
8\end{array}$} & \multirow{2}{*}{$\begin{array}{c}\begin{array}{c}\text { No. with Results of } \\
0 \cdot 3 \text { or Less }\end{array} \\
8\end{array}$} \\
\hline Lupus Erythematosus & $\cdots$ & . & . & $\cdots$ & . & . & . & . & $\cdots$ & & \\
\hline \multirow{2}{*}{ Amyloidosis } & \multirow{2}{*}{$\cdots$} & \multicolumn{6}{|c|}{ Secondary to rheumatoid arthritis } & . & $\cdots$ & 5 & 3 \\
\hline & & \multicolumn{6}{|c|}{ Secondary to tuberculosis and sepsis } & . & $\cdots$ & 2 & 2 \\
\hline Jaundice & $\cdots$ & $\cdots$ & $\cdots$ & $\cdots$ & $\cdots$ & $\cdots$ & $\cdots$ & . & $\cdots$ & 16 & 10 \\
\hline \multirow{2}{*}{ Rheumatoid Arthritis } & \multirow{2}{*}{$\cdots$} & \multicolumn{6}{|c|}{ Juvenile (aged under 20) } & . & $\cdots$ & 13 & (1 with amyloid) \\
\hline & & & & Adult & . & $\cdots$ & $\cdots$ & $\cdots$ & $\cdots$ & 53 & $\begin{array}{l}4 \\
\text { (2 with amyloid, } \\
1 \text { suspected amyloid) }\end{array}$ \\
\hline \multicolumn{2}{|c|}{ Anasarca and Polyserositis* } & $\cdots$ & $\cdots$ & $\cdots$ & $\cdots$ & $\cdots$ & $\cdots$ & $\cdots$ & $\cdots$ & 1 & 1 \\
\hline \multicolumn{2}{|c|}{ Leukaemia with Cryoglobulins } & . & $\cdots$ & $\cdots$ & . & . & $\cdots$ & . & $\cdots$ & 1 & 1 \\
\hline
\end{tabular}

* This patient had multiple serositis and oedema without renal disease. Four other cases of nephrotic syndrome had normal fading rates

TABLE III

FADING RATES IN PATIENTS WITH LUPUS ERYTHEMATOSUS, AMYLOIDOSIS, AND JAUNDICE

\begin{tabular}{|c|c|c|c|c|c|c|c|}
\hline \multirow{2}{*}{ Disease } & \multicolumn{2}{|c|}{ Number of Cases } & \multirow{2}{*}{$\underset{(y r s)}{M}$} & \multirow{2}{*}{$\begin{array}{l}\text { Number of Cases } \\
\text { with F.R. of } \\
0 \cdot 3 \text { or Less }\end{array}$} & \multirow{2}{*}{ Mean F.R. } & \multirow{2}{*}{$\begin{array}{c}\text { Standard Error } \\
\text { of Mean }\end{array}$} & \multirow{2}{*}{$\begin{array}{l}\text { Standard } \\
\text { Deviation }\end{array}$} \\
\hline & Male & Female & & & & & \\
\hline Lupus Erythematosus & 1 & 7 & 38 & 8 & $0 \cdot 13$ & 0.04 & $0 \cdot 10$ \\
\hline Amyloidosis .. & 4 & 3 & 40 & 5 & $0 \cdot 24$ & $0 \cdot 08$ & $0 \cdot 21$ \\
\hline Jaundice & 8 & 8 & 51 & 10 & $0 \cdot 31$ & 0.06 & $0 \cdot 24$ \\
\hline
\end{tabular}




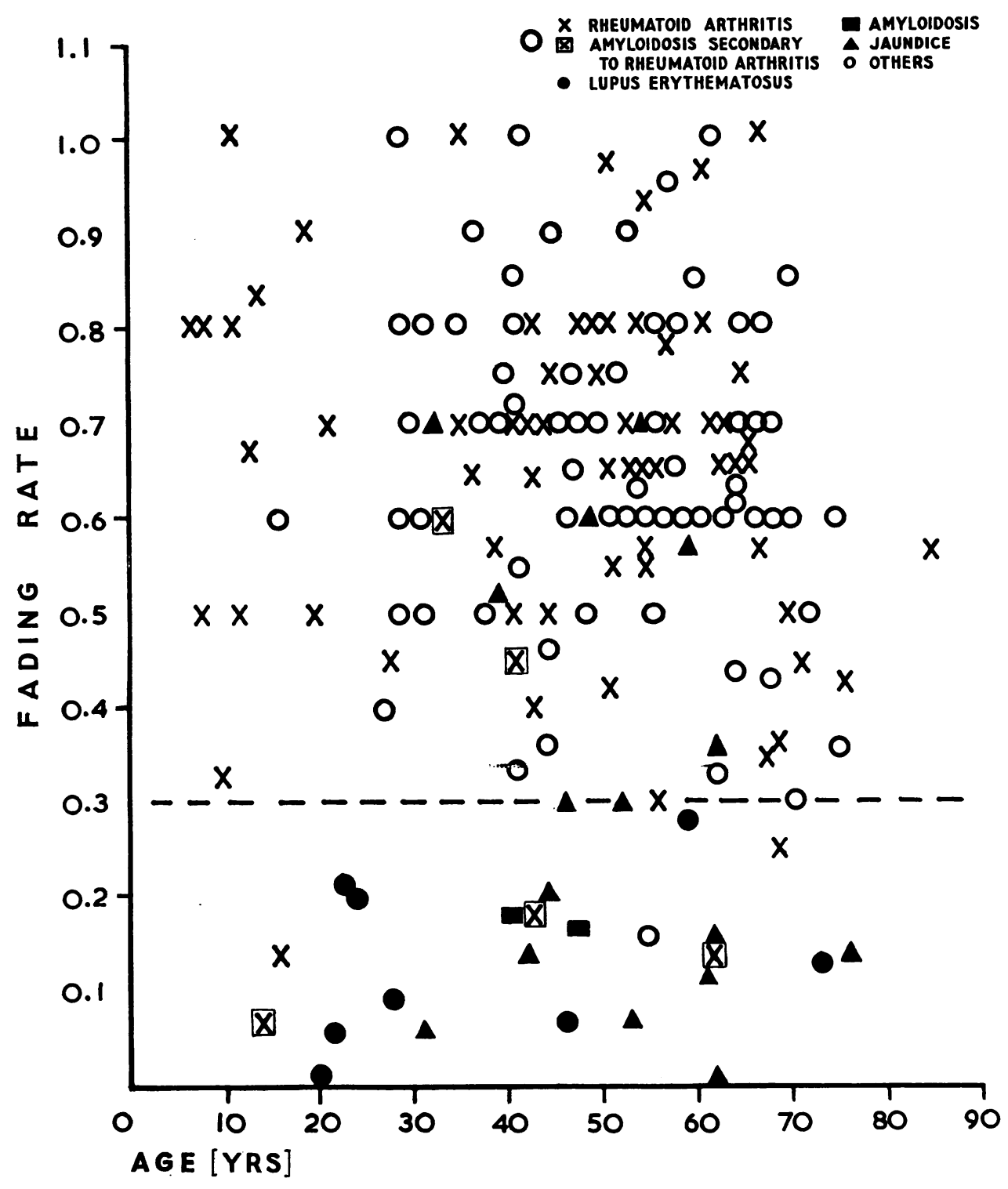

Fig. 1.-Scatter diagram of F.R. according to age and diagnosis.

the dye to be present as minute, possibly intracellular, particles. No staining of collagen fibres was seen. Sections stained with haematoxylin and eosin revealed no histological abnormality.

Amyloidosis.-Seven patients were tested; in five the amyloid was secondary to rheumatoid arthritis, in one to pulmonary tuberculosis, and in the other to post-operative bronchopleural fistula.

Three of the five rheumatoid subjects with amyloidosis and the two non-rheumatoid cases of amyloidosis had F.Rs. of less than $0 \cdot 3$.

The mean F.R. for this group was $0 \cdot 24( \pm$ S.E. 0.08 (S.D. $0 \cdot 21)$ ), statistically different from that of the control group $(p=<0.001)$. 
In all but one patient, in whom the diagnosis was confirmed at autopsy, intravenous Congo red tests were carried out. In Fig. 2 these are plotted against the F.R.; although the numbers are few there is a tendency for a high Congo red clearance to be associated with a slow rate of skin fading.

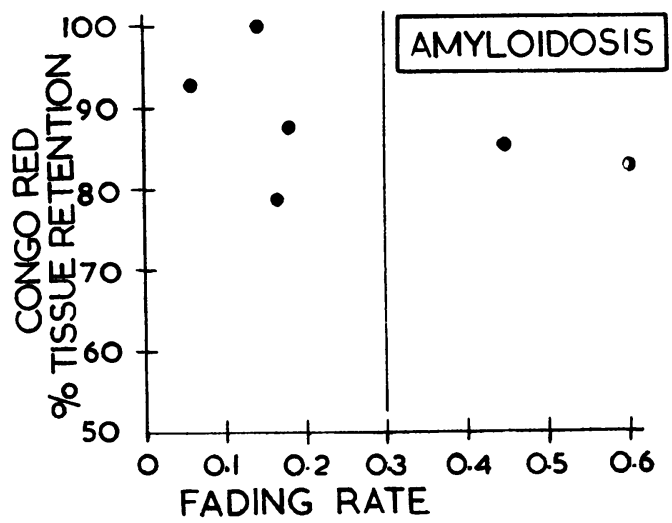

Fig. 2.-F.R. and Congo red retention in cases of amyloidosis.

In each of these patients the area of skin injected appeared normal, and in one histological examination of the injection site at autopsy failed to reveal evidence of local amyloidosis.

Jaundice.-Sixteen subjects were examined. The results are given in Fig. 3 and Table IV.

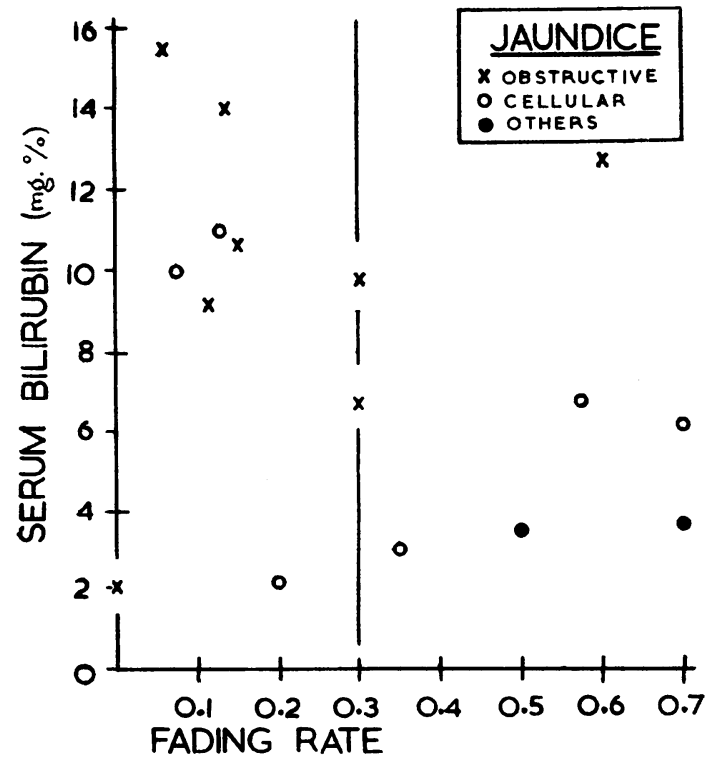

Fig. 3 -F.R. and serum bilirubin in cases of jaundice.
TABLE IV

RESULTS IN PATIENTS WITH JAUNDICE

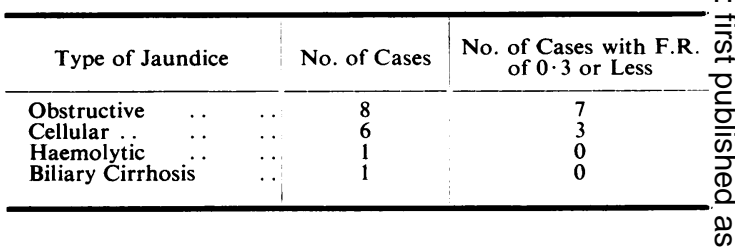

There was no correlation between plasma bili- $\vec{\bullet}$ rubin, alkaline phosphatase, or flocculation tests: and the F.R.

In one patient with obstructive jaundice, the F.R. returned to normal, after surgical relief of the obstruction, before the serum bilirubin had fallen $\vec{\infty}_{\infty}$ to normal.

Although once again the numbers are small, slowio rates of fading were seen most frequently in patients응 with obstructive jaundice.

An attempt was made to assess the effect of bile salts on the F.R. by incorporating sodium tauro- $\frac{\mathrm{N}}{\mathrm{O}}$ cholate into the Congo red solution used for injec- $\exists$ tion. The salt was added in a concentration of $\vec{c}$ $1 \mathrm{mg}$. to $0 \cdot 1 \mathrm{ml}$. 1 per cent. Congo red. This 0 solution was compared with the aqueous 1 per cent. Congo red in six patients, and no difference in F.R. was observed.

As these abnormal groups were discovered in the main rheumatoid and non-rheumatoid groups it seemed wise to reconsider the mean F.R. of both $\stackrel{\varrho}{\vec{T}}$ these groups again, after excluding the patients with윽 lupus, amyloidosis, and jaundice, who are given in Table III. These results are shown in Table V, in which the mean values for the rheumatoid and nonrheumatoid groups are in even closer agreement. Despite the minor differences in technique it will be noted that the mean F.Rs. in the present series 3 . closely correspond with those in Shannon's controlo group, i.e. 0.67 (S.D. 0·24).

TABLE V

RESULTS AFTER EXCLUDING PATIENTS FROM TABLE II

\begin{tabular}{|c|c|c|c|}
\hline Male and Female & Mean F.R. & $\begin{array}{c}\text { Standard Error } \\
\text { of Mean }\end{array}$ & $\begin{array}{r}\text { Standard } \\
\text { Deviation }\end{array}$ \\
\hline Non-Rheumatoid & $0 \cdot 65$ & 0.022 & $0 \cdot 19$ \\
\hline$\overline{\text { Rheumatoid }}$ & 0.65 & 0.022 & $0 \cdot 17$ \\
\hline
\end{tabular}

The results presented here are in contrast with 0 those reported by Laine and others (1956) whose group of 55 rheumatoid arthritis patients were not ${ }_{\Omega}^{\Phi}$ defined as regards age and disease activity. The work of Shannon and others (1957), however, 
suggests that young rheumatoid arthritics resorb Congo red at a considerably slower rate than control children in the same age group. The few young patients in this series failed to show a consistently slow F.R. In older patients we have shown no correlation between age and fading rate either in the rheumatoid arthritic group or in the control group, both of which showed similar rates of fading.

The abnormal results in the lupus, amyloid, and jaundiced patients are of interest, but the mechanism of their production is difficult to determine. No common factor could be found in the groups of patients which gave these abnormal results.

Not all the patients with abnormal F.Rs. were treated with steroids, and no significant alteration occurred when patients were treated with cortisone or its analogues.

It is possible that the reduction in skin, blood, and lymphatic flow in seriously ill patients could be responsible for the delay in resorption in some of these patients. However, only a small number of the patients with abnormal fading rates were seriously ill at the time of testing, while normal results were seen in dying patients in the control group.

Abnormalities of serum proteins are common in patients with lupus, amyloidosis, and hepatocellular jaundice. Electrophoresis of their sera frequently shows a low serum albumin level and raised gamma globulin levels. Since Congo red is transported in the blood in combination with albumin, the lowered level of serum albumin might be responsible for the decreased rate of resorption from the skin. However, since four patients with the nephrotic syndrome and low serum albumin levels had normal F.Rs., this phenomenon may be related more closely to altered tissue "plasma protein" (Humphrey, Neuberger, and Perkins, 1957).

Clearly, further investigation is required to establish the factors producing the abnormality of fading rate in these groups of patients. Histological examination of skin from the injection site in patients with abnormal fading rates may establish accurately the site of deposition of the Congo red.

\section{Summary}

The vital staining of the skin with intracutaneously injected Congo red solution was investigated in 162 rheumatoid and non-rheumatoid subjects. No difference was found in the fading rates between adult rheumatoid arthritis patients and a control group of non-rheumatoid patients.

The activity of the rheumatoid disease did not influence the fading rate and no correlation could be found with age in either group.

Abnormally slow resorption was found in each of eight subjects with lupus erythematosus and gross delay was observed in two.

Patients with amyloidosis showed a slow fading rate in the absence of histological abnormality of the skin.

Jaundice delayed resorption in a high proportion of subjects: this was most noticeable in obstructive jaundice.

No common factor could be found to account for the production of these abnormal results.

\section{REFERENCES}

Bennhold, H. (1923). Dtsch. Arch. klin. Med., 142, 32.
Dixon, A. St. J., Ramcharan, S., and Ropes, M. W. (1955). Ann. rheum. Dis., 14, 51 .

Humphrey, J. H., Neuberger, A., and Perkins, D. J. (1957). Biochem. J., 66, 390.

Laine, V., Holopainen, T., and Mäkinen, P. (1956). Acta rheum. scand., 2. 31.

Nomland, R. (1936). Arch. Derm. Syph. (Chicago), 33, 85

Philpott, O. S., and Freshman, A. (1936). Ibid., 33,970.

Shannon, F. T., Fessel, W. J., and Bywaters, E. G. L. (1957). Ann. rheum. Dis., 16, 225.

\section{DISCUSSION}

Prof. BYWATERS: I do not think there is much to add to this paper. There are very striking differences in patients in the rate of fading, and this is an attempt to give a quantitative assessment to the phenomenon, to try and account for the differences. We do not feel that we have got very far with this problem. The differences may possibly be due to the raised plasma globulins of these patients which are reflected in the tissue proteins, but that is merely speculation and we should be grateful for suggestions.

Dr. C. Ragan (New York): Could you not show to which protein the Congo red is bound by electrophoresis with this test; and which is the protein which is separated?

Dr. A. ST. J. Dixon (Hammersmith): It is not possible to do an electrophoresis of a mixture of dye and serum, as the Congo red binds to the paper and does not move.

DR. J. BAll (Manchester): I think it may be worth mentioning a little experiment which Dr. Dixon and I tried out shortly after reading a paper about the Congo red retention test for amyloid which suggested that retention was sometimes seen in rheumatoid patients when amyloidosis had been unsuspected. At the time we wondered whether there were tissue components other than amyloid tissue which bound the dye. We took out some rheumatoid nodules which we thought might retain Congo red, and when some of the fibrinoid was put into the aqueous solution of Congo red one could see staining. We added the Congo red to serum in concentrations which we imagined would obtain in the ordinary Congo red test, and under those circumstances there was no take-up by the tissue at all; it was thought that the serum was preferentially binding the Congo red. 
It may be that intradermal staining is due to the formation of an insoluble dye-protein complex which is taken up by the connective tissue cells locally.

Prof. Bywaters: Laine, Holopainen, and Mäkinen (1956) studied the rate of disappearance from the skin of intradermally-injected aqueous Congo red solution. They observed a slower rate of fading in subjects with rheumatoid arthritis than in a control group. Shannon, Fessel, and Bywaters (1957), using a saline solution of Congo red, demonstrated delayed fading in juvenile rheumatoid arthritis, most marked in the younger age groups, and possibly related to the increased tissue retention of intravenously injected Congo red, demonstrated by Dixon, Ramcharan, and Ropes (1955). This paper reports the fading rates in 66 subjects with rheumatoid arthritis (mainly adults) compared with those in 96 controls including healthy subjects and hospital in-patients with miscellaneous diseases.

$0.1 \mathrm{ml}$. aqueous Congo red solution was injected intradermally into the arm and the stained area compared at $24 \mathrm{hrs}$ and at 7 days with a set of standard colours prepared from serial dilutions of Congo red solution. The results were expressed as a fading rate. Analysis of the results failed to show a delayed rate of fading in the adult rheumatoid patients compared with normals. There was no relation to active disease, raised erythrocyte sedimentation rates, or positive Rose-Waaler tests; nor did age or sex influence the fading rate. Abnormally slow fading rates were seen in 28 subjects, of whom only six suffered from rheumatoid arthritis. Of these six, one had suspected and three had proven secondary amyloidosis. Two patients with amyloidosis secondary to other diseases had slow fading rates. Eight patients with lupus erythematosus, seven of whom had systemic disease, all showed delayed fading from apparently healthy skin. Sixteen jaundiced patients were studied and ten were found to have slow fading rates; of these, seven had obstructive jaundice. There was no correlation with serum bilirubin or alkaline phosphatase levels. Some of the subjects with rheumatoid arthritis and all of those with lupus were receiving steroid hormones at the time of testing. To exclude these hormones as a factor in the delayed fading rate, tests were carried out both before and during steroid treatment in nine patients; no significant difference was observed in the fading rates. The incorporation of hydrocortisone or bile pigments into the Congo red solution before injection similarly failed to influence the rate of fading.

No common factor could be found to explain this apparent dermal avidity for Congo red in the three groups of patients, but all three have abnormal serum proteins and perhaps abnormal tissue proteins too in? consequence.

Résorption du rouge Congo injecté par voie intradermique

\section{RÉSUMÉ}

On étudia chez 162 sujets rhumatisants et non rhumatisants la coloration vitale de la peau aprèsy l'injection intradermique d'une solution de rouge Congow On n'observa pas de différence entre les vitesses de décoloration chez les rhumatisants arthritiques adultes et chez les témoins non-rhumatisants.

Le degré d'activité de la maladie rhumatismale n'influença pas la vitesse de décoloration et on ne trouvầ pas de corrélation avec l'âge dans aucun groupe.

Une résorption anormalement lente fut observée cheztous les huit sujets atteints de lupus érythémateux efo il y eut un fort délai chez deux d'entre eux.

Les malades atteints d'amyloïdose accusèrent une vitesse de décoloration faible en l'absence de toute anomalie histologique de la peau.

Un ictère ralentissait l'absorption chez un granck nombre de sujets; ceci était particulièrement prononc dans l'ictère par obstruction.

On ne put trouver aucun facteur commun qui expli= querait comment se produisent ces résultats anormaux.

Resorpción del rojo Congo inyectado por vía intradérmicag

\section{Sumario}

Se estudió en 162 sujetos reumáticos y non-reumáticošํำ la coloración vital de la piel después de inyeccioneß̊ intradérmicas de una solución de rojo Congo. No sę vió diferencia alguna entre las velocidades de descolori miento en los sujetos adultos con artritis reumatoide 음 los testigos non-reumáticos.

La actividad de la enfermedad reumática no ejerciōo influencia alguna sobre la velocidad de descolorimient $\vec{\Phi}$ y no se encontró una correlación con la edad en ningún grupo.

Se observó una resorpción anormalmente lenta en los ocho casos de lupus eritematoso y en dos de ellos la demora fué considerable.

Los enfermos con amiloidosis acusaron una velocidad de descolorimiento débil en la ausencia de toda anomalíą histológica de la piel.

La ictericia demoraba la absorpción en una gran proporción de los casos, particularmente al tratarsed de ictericia por obstrucción.

No se encontró ningún factor común que pudier explicar estos resultados anormales. 